山形県立川町「長者池」に関する二, 三の湖沼学的 知見

\section{坂野文雄・加藤武雄}

長者池は山形県東田川郡立川町中島地内の立谷沢川 （加藤 1956）右岸丘陵地帯に湛水する湖沼で，その 湖面標高は $105 \mathrm{~m}$ である。1959年 11 月 28 日, はじめて 星野隆一氏が鍾測を行っと深度図を作製されたが，わ れわれはこれをもとにして湖盈形態に関する諸計測値 を計算し，第 1 表のような結果を得た。また，同氏は 当日湖心部に沶いて，水温， $\mathrm{pH}$ などの観測を行ってい るが，全層にわたって湖水が循環していることが知ら れる(第 2 表)。

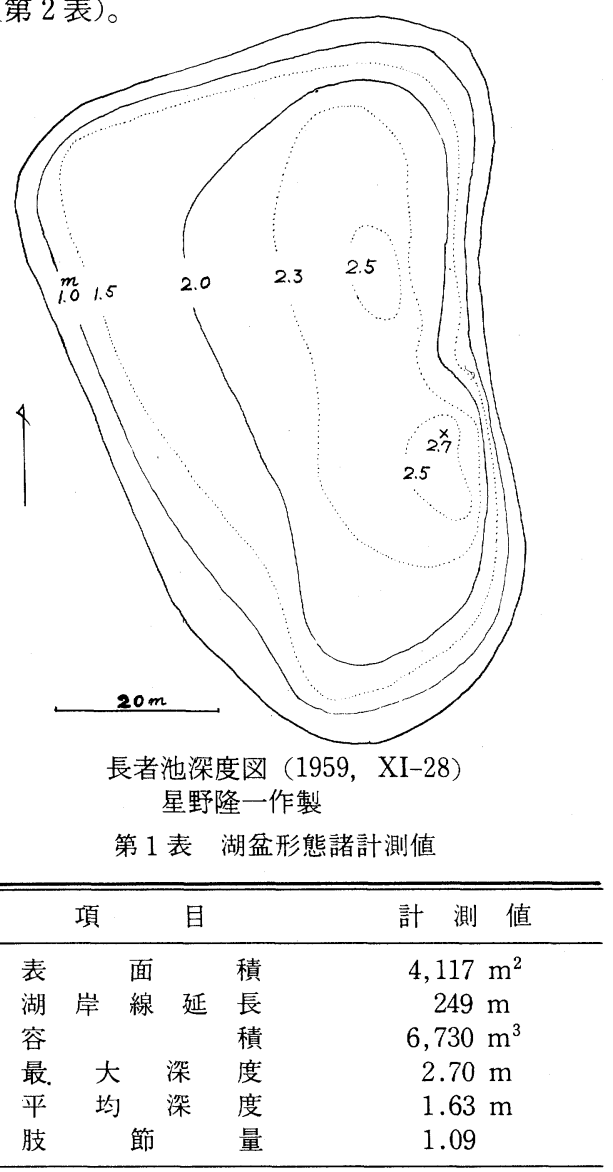

われわれは, 1972 年 6 月 25 日に, 水温・水質の垂直分 布に関する詳細な観測を行ったが，豪雪地帯のこの地 域でも初夏に入り, 水温・化学成層の発達が進行しつ つあることが認められた（第 3 表）。また, 堆積岩地帯
第 2 表 水温・水質の垂直分布 (1959, XI -28)

\begin{tabular}{cccc}
\hline \hline 深 度 $(\mathrm{m})$ & $\mathrm{Tw}\left({ }^{\circ} \mathrm{C}\right)$ & $\mathrm{pH}$ & $\mathrm{RpH}$ \\
\hline 0 & 7.4 & 5.8 & 6.2 \\
1.0 & 7.4 & 5.9 & 6.2 \\
1.5 & 7.4 & 5.9 & 6.1 \\
2.3 & 7.4 & 5.8 & 6.1 \\
\hline \multicolumn{4}{c}{ 透明度 : $2.00 \mathrm{~m}$, 水色 XV }
\end{tabular}

第 3 表 水温・水質の垂直分布 (1972, VI - 25)

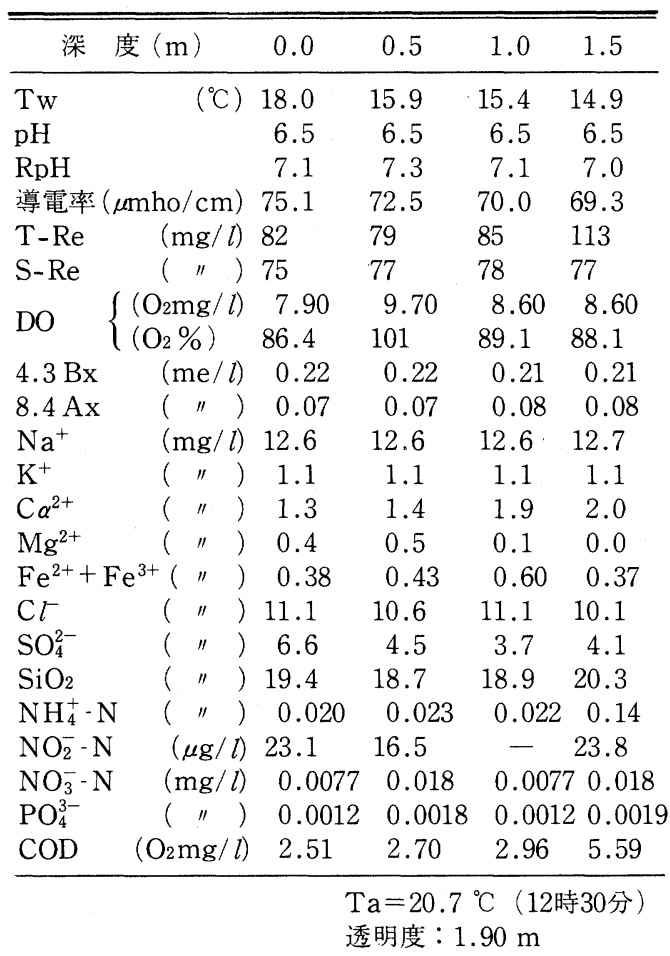

で $\mathrm{SiO}_{2}$ の溶存量の多いことが特色であり, 溶存主成 分は豪雪地帯の他の湖沼（加藤 1976）と持なじように， 塩化ナトリウムであることも明らかになった。

深度図扣よび第 2 表の資料は上野益三博士の御好意 によって加藤に贈られたもので，同博士に深謝の意を 表する。

(1976.8.13 受理)

\section{文献}

加藤武雄 (1956)：立谷沢川（山形県）の陸水学的研究 地理評 $29559 \sim 567$ (1976)：山形県沼山大沼の湖沼学的研究 東 北地理 $28 \quad 94 \sim 102$

\title{
Some Limnological Notes on Lake Chôja-ike, Yamagata Prefecture
}

